$J J M L L$

\title{
The Pivotal Role of Small Talk in Distance Teaching During Covid 19 Curfew Period
}

\author{
Rula Abu-EIrob *, Ahmad Tawalbeh \\ Department of English, Irbid National University, Jordan
}

Received on: 13-9-2020

Accepted on: 22-2-2021

\begin{abstract}
Human talk includes parts that are considered essential to share the understanding of the talk while some other parts may be viewed as just space filler, named 'small talk' (henceforth ST) (Coupland et al. 1992). This talk gains its name perhaps because it occurs at the side or margin of the 'main talk' (henceforth MT) as it may not contribute to the core of a talk. This does not mean to neglect this kind of talk as it could show a crucial role in participants' MT (Abu-Elrob 2019b). Therefore, the present paper aims to give ST the attention it deserves by analyzing its occurrence in remote classroom environment to find whether it is only talk filler or purposive. This study also conducted an analysis of ST types and the linguistic features realizing the occurrence of ST. For a deep analysis of the data (classroom MT and ST), the conversation analysis (CA) framework was used to analyze the sequences and turns. The findings showed the benefits of ST to the learning process in general and to the main topic of the lesson in particular. The findings provide insights into the importance of ST in the learning environment and how it can be developed as a strategy to improve this environment.
\end{abstract}

Keywords: Distance Teaching, Classroom Talk, Small Talk, Conversation Analysis.

\section{Introduction}

1.1 Jordanian socio-academic context during Covid-19 pandemic

On 14 March 2020, the Jordanian government announced the beginning of a lockdown as a result of Covid 19 spreading. This lockdown has impacted the education process in private and public sectors of kindergartens, schools and universities. As a result, the Jordanian government has ensured the continuing of the learning process through distance learning. For example, televised lessons have been broadcasted for all school students, using the education platform DARSAK. Also, a web page (Noorspace) was setup to help teachers track the students' attendance and engagement.

In addition, the availability of different online educational platforms, such as Microsoft Teams and Google Classroom, has offered varied options to facilitate running the teaching process in schools and universities. Teachers have been able to deliver lessons, share materials and tasks with students and upload exams on such platforms. Moreover, interactive virtual classes via online educational platforms,

\footnotetext{
๑ 2022 JJMLL Publishers/Yarmouk University. All Rights Reserved,

${ }^{*}$ Doi: https://doi.org/ 10.47012/jjmll.14.1.9

* Corresponding Author: rula_n1981@yahoo.com
} 
such as Microsoft Teams, Zoom and Skype, have been created allowing interaction between teachers and students. Also, social media platforms, such as Messenger and WhatsApp have also been used by teachers and students to share learning content.

However, teachers and students have had to adapt to the new learning environment and to face any potential challenge. Teachers have entered the new teaching settings and had to use technology in teaching, on which they may not have received sufficient training. Students have had to rely on the available resources to them. On the one hand, some students had access to distance learning and could benefit from the digital devices they already owned to proceed with their education. On the other hand, there was a lack of the needed digital resources or the infrastructure required to make the distance learning possible. In this case, school students could benefit from the television to follow the broadcasted lessons, but they would be only recipients as they missed the advantage of the interaction aspect occurring in normal classrooms.

Distance teaching in the new circumstances imposed by Covid-19 pandemic is the available solution to aid students in their education. However, students miss the value of socio-academic interaction with their teachers, faculty members and peer students in schools and universities. These institutions are vital premises where students can meet and develop their communication skills to be active members in the society they live in.

\subsection{Teacher-student interaction}

Classroom talk has been characterized as a speech exchange system which is institutional in nature with highly predictable patterns (Case 2019). Achieving the aims of a classroom talk might be affected by different factors like teacher - student relationship. A positive relationship between a teacher and students impacts positively the students' motivations and the outcomes of learning process (Luz 2015). Luz maintains that the sense of security and trust in teacher- student relationship contributes to the academic success of students because they become more focused and hard workers. When students realize that they are welcomed in the classroom, they are more likely to be engaged and motivated. Therefore, the role of the teacher in the classroom affects the perception the student has about the teacher-student relationship and the classroom environment. This in turn can influence students' achievement. Moreover, teacher student relationship impacts students' behavior (Leff et al. 2016). Any deficiency in this relationship negatively affects students' behavior because they will neither listen to their teachers nor trust them (Boynton and Boynton 2005). In addition, a disrespectful relationship between the teachers and students has negative effects on teachers' feelings like causing stress, which will be reflected on the classroom environment (Varga 2017). It can be said that teacher-student relationship can positively motivate students and enhance their interest toward learning (Maulana et al. 2013). This in turn plays a critical role in their endeavor to learn, perform and behave (Varga 2017).

Because of the crucial role of teacher-student relationship in classroom achievement, it would be useful to analyze teacher-student talk. An analysis of this talk involves an analysis of the main classroom talk and what may be referred to as ST. 
The Pivotal Role of Small Talk in Distance Teaching During

Covid 19 Curfew Period

\subsection{Small talk}

The original concept of ST is 'Phatic talk' (Coupland 2000) which relates to a space-filling talk. Malinowski (cited in Coupland et al. 1992, 208) called ST 'phatic communion' and defined it as 'a type of speech in which ties of union are created by a mere exchange of words, when people aimlessly gossip'. In a workplace, ST is 'empty' talk because it includes non-serious talk and can be dropped smoothly from an interaction (Turner 1973; Holmes 2000). ST has different terms, such as social talk, minimal conversation and casual conversation (Jaworski 2002), off-task talk (Markee 2005), off-topic chat (Macdonald 2016) and side talk (Abu-Elrob 2019b). All these different terms represent non-work related talk. This form of talk can be considered, as Abu-Elrob reported, a shift from the participants' main topic. It may include gossip, chat, time-out talk, humor and jokes.

Moreover, ST occurs in different types, such as Topicalized ST (TST), brief ST, minimal ST, ongoing ST, compliments, jokes and humor (Hudak and Maynard 2008, 2011). Hudak and Maynard (2011) differentiated between topicalized ST (TST), brief ST, minimal ST and on-topical ST. They defined TST as a shift from the main topic to a new line of talk that is independent from the institutional identity of participants, unlike the on-topical ST which is dependent on the ongoing talk. In TST, participants collaborate to develop ST wherein the new topic might be about a current event, weather, shared interests, or personal biography. On the other hand, there is no subsequent collaborative engagement in minimal ST, as it is met with minimal response although it occurs across more than one turn. As for brief ST, it is the preferred topic that is met with no uptake.

It was found by Coupland et al. (2000) and Holmes (2000) that ST occurrence has a supportive role in the institutional context and it develops the interpersonal relationships. It is proved that ST helps building solidarity which can be reflected on the atmosphere of the workplace (Holmes and Stubbe 2003). It may also reduce the unpleasant feeling in embarrassing situations (Macdonald 2016). Moreover, ST might help release the stress of work (Valencia 2009). Abu-Elrob (2019b) also found that ST has a crucial role in supporting work talk. Abu-Elrob observed that ST helped doctors convince patients in diagnosis and treatment suggestions. She clarified that the occurrence of ST does not only have interpersonal and relational functions, but also supports the main topic of the medical agenda.

The occurrence of ST in classrooms might be used to build rapport talk that tends to take place during pre- and post-lesson phases as warm up and wrap-up talk (Case 2019). ST can play a role in improving L2 leaners communicative competence during their participation in cross-cultural communication (Luk 2004). Luk suggests that students and teachers of English language should have the opportunities of experiencing the joy of using a foreign language for meaningful communication, which might happen when participants open up themselves to more non-institutional talk contexts.

\subsection{Research questions and hypothesis}

This study hypothesizes that ST may occur in remote classes, as it occurs in normal classrooms, and it might have a role in classroom talk. Therefore, this study comes to answer the following questions:

1. What are the linguistic features that signal the beginning and ending of ST? 
2. What are the types of ST occurring in the present data?

3. What is the role of ST in distance teaching?

\section{Literature review}

The analysis of ST in classroom interaction does not receive much attention from researchers. In an example of second language teaching, Markee (2005) discussed the occurrence of what is called 'an interactional gap opened up' which causes the occurrence of ST. Markee explains that this gap occurred when students are encouraged to shift to a new topic and they are not ready to open it. In other cases, ST occurs when students do activities in which they are allowed to shift to chat with their classmates to know each other and to find what is common between them (Luk 2004).

Another example on ST in classroom settings, Sharma (2014) tackled the occurrence of ST, along with silence and dominance, in an advanced academic writing class. Sharma's study is based on showing teachers a video which represents students' interaction in a group work. The teachers had the chance to comment on the video and explain the occurrence of ST. The teachers reported that ST occurred when students answered questions that require emotional responses; some of these answers were relevant to the main topic of discussion. However, this study discussed only one video on ST on which the teachers give comments without analyzing the classroom talk using the CA framework. It only shows the occurrence of ST without explaining its role or its relation to the classroom topic.

The occurrence of ST in classrooms was discussed in a reviewed study by Langer-Osuna (2018). The focus of her study is on the role of ST in collaborative mathematic learning. She suggested that ST interaction may support collaborative learning because it gave students the chance to be engaged in and join existing collaborations before shifting back to task. It also improved students' abilities in discussing topics beyond school mathematics and opened the gate for the collaboration itself.

The previous studies examined ST in normal classroom teaching environment. Meanwhile, the only study, as far as the researchers know, that investigated the role of humor (as a type of ST, see section 1.3) in distance learning environment is McCabe et al. (2017). They found that humor helped attract students' attention to the class, bridge the gap of distance teaching and improve the relationship between teachers and students. However, this study focused on ST from humor perspective only and has not analyzed other forms of ST occurrences, which show a shift from the main topic.

It can be seen from the above studies that ST occurs in a face-to-face interaction. Such settings can give teachers a chance to monitor students' ST by observing their attention and pulling their talk back to the main topic when it goes further than desired. At this point, it can be asked what happens if ST occurs in distance teaching? Can teachers control ST occurrence to serve the distance learning environment? This study comes to find if there is a relationship between ST (of all of its types of occurrences) and the classroom MT in distance teaching classes in Jordan during Covid 19 curfew period. These classes were originally regular normal ones, but as a result of the start of Covid 19 in Jordan, the government has kept running these classes using online devices only. 
The Pivotal Role of Small Talk in Distance Teaching During

Covid 19 Curfew Period

\section{Theoretical background}

$\mathrm{CA}$ and discourse analysis (DA) are both qualitative in nature and reflect the concern of ethnomethodology which is how social action is accomplished through the competencies of participants. They are similar in the approaches and assumptions at the broad level, but the deeper we go to the methodological assumptions, the significant differences appear. The main concern of both CA and DA is language in use. DA "studies language and language use as evidence of aspects of society and social life" (Taylor 2013, 7). CA can be considered a part of DA as it the systematic analysis of social interaction in everyday life (Hutchby and Wooffitt 1998). Moreover, research in DA is concerned with written and spoken aspects of language, such as informal interviews, published research articles, newspaper reports and wider range of verbal and textual materials. CA researchers study verbal interactions by analyzing turns and sequences. Therefore, DA research covers areas that are of interest to conversation analysts.

\subsection{CA framework}

An analysis of turns and sequences uses CA framework which is concerned with studying the action which is manifested throughout the talk. It focuses on the speakers' actions at a specific point of interaction. Therefore, as ST occurs at a specific point of talk, the present study uses this framework. It was used to analyze teacher-students' interaction and the actions performed by such interaction. These actions include the departure from the main classroom topic, which is either developed or rejected.

To conduct turns-at-talk analysis, CA relies on the following principles (Seedhouse 2013, 94-95):

1. There is an order at all points of interaction: the talk in interaction is systematically organized, deeply ordered, and methodic.

2. Contributions to interaction are context shaped and context renewing. Contributions are context shaped in that they cannot be adequately understood except by reference to the sequential environment in which they occur and in which participants design them to occur. Contributions are context renewing in that they inevitably form part of the sequential environment in which a next contribution will occur.

3. No order of detail can be dismissed a priori as disorderly, accidental, or irrelevant. This principle can be seen to underlie the development of the highly detailed CA transcription system, its minute analysis of the details of naturally occurring data, and its highly empirical orientation.

4. The analysis is bottom up and data driven; we should not approach the data with any prior theoretical assumption or assume that any background or contextual detail is relevant unless there is evidence in the details of the interaction that the participants themselves are orienting to them.

These principles serve the present analysis as it considers any deviation from the sequence of the MT

is ST. Also, the analysis relies on considering the sequential environment which shapes the classroom talk to help understand the talk with its organization and what can be considered departure from that talk. In 
addition, this study deeply analyzes the turns and then the sequences; therefore, bottom-up processing was adopted (see section 4 below).

\section{Methods}

CA framework was used to analyze and investigate ST in classroom interaction and to find whether it is relevant to the main topic or not. This framework helps conduct a detailed sequential analysis of the data. It relies on using bottom-up processing so that the researchers used it to analyze the linguistic features at the bottom level, the talk turns at a higher level and finally the sequences.

CA framework uncovers the underlying system of a conversation to show how participants interpret each other and how they share the understanding of the interaction process. In CA, participants' contributions are 'context- shaped' and 'context- renewing'. It is 'context- shaped' as the design of participants' contributions can be understood by referring to the sequential environment in which these contributions occur. It is 'context- renewing' as the production of a new action depends on understanding the context. The new action indicates that a new context is created wherein ST may appear. By considering such roles of the context, the researchers group the turns that form a sequence by understanding the sequential environment shaping the classroom talk. This help the researchers recognize the transition points at which the participants shift from the class MT to ST and then pull the talk back to the main agenda.

\subsection{Participants}

In the current paper, a total of 18.5 hours were audio recorded for undergraduate and graduate students in different disciplines during Covid 19 curfew (on March-May 2020). The data included 108 undergraduate students and 10 graduate students. Ethical approval was obtained from participants before collecting the data.

\subsection{Procedures of data collection and analysis}

The data collectors, a professor and two students, had the responsibility of recording the classroom conversations. The professor has an official page on Facebook where he recorded the conversations. The students sent the recorded data to the researchers via email. The researchers, in their turn, listened to those conversations and analyzed their sequences using the sequential approach advocated in CA, aimed to identify ST occurrences in classroom settings.

Transcription process, in CA, is essential to investigate particular features in an interaction. In this study, Jefferson's transcription system was used to analyze the data, as it is most commonly used in analyzing CA data. It would show clear representation of the data as they sound to the ear. The interactions were written in their original language (Arabic). A transcription to English was provided in a second line by using the phonemes of Spoken Jordanian Arabic that were used by Al-Harahsheh (2015). After that, the functional translation was given in a third line. Details such as pauses and hesitation are kept in their position in the translated lines. This is supported by Aronsson and Cederborg $(1997,85)$ who 
The Pivotal Role of Small Talk in Distance Teaching During

Covid 19 Curfew Period

stated, 'The number of overlaps, pauses, hesitation, hedges, self-editings, and so forth are kept constant, as is their location in relation to turn junctures'.

All the participants' names that were mentioned in the interactions were omitted for anonymity. Two obstacles appeared while translating the data; firstly, the researchers did not represent the reactions of the participants because the data does not include video recording. Secondly, there were problems in hearing some parts of the conversations due to participants interrupting each other and errors in the internet connection.

\section{Results and discussion}

In most parts of the classes, there was not much interaction between participants as the lecturer was mainly taking a role similar to that of a presenter who delivers information. The limitation of the interaction may be due to the nature of the distance teaching classes as it did not help the participants to keep the channel open between them. They could not hear each other most of the time, as the internet connection was not effective enough. The interaction appears in question - answer sequences or in the form of a comment on delivered information. In spite of the limitation of the interaction, ST has taken place in most of the conversations. It is apparently related to the MT of the lesson or to the whole learning process. This finding matches with Abu-Elrob's (2019b) study which shows that ST is relevant to the main topic of the medical interaction. She observed that doctors support the main purpose of the medical talk by moving away from the main topic to discuss topics which seem irrelevant to the consultation. Abu-Elrob adds that the relation between ST and the MT becomes evident when the participants pull the conversation back to the medical agenda.

In the current paper, the focus is on the conversations that show the relevancy of ST. In some examples, ST relates to the MT of the class and supports it, as seen in extracts 1-5 whereas it appears to be relevant to the learning process in general in extracts 6-9. Also, the analysis below identifies the type of ST for each extract.

\subsection{ST relevant to the main topic}

In Extract 1, while the lecturer and his students were discussing the mock exam, the former shifted to ST in the middle of the conversation.

\section{Extract 1}

الدكتور: الأربعاء بتفق أنا و اياكم. الإمتحان خمس دقائقلافقط

3. ?il?arBiçaa? ?iBnitafiq ?anaa Wa ?iyaakom ?i?imtiћaan Xamis Daqa?iq $\downarrow$ faqat?

We will discuss this on Wednesday. The exam will be only five minutes

$$
\text { انتم؟ مش وصلكم كل واحد مستج لوحده؟ (0.2) انه في امتحان؟ }
$$

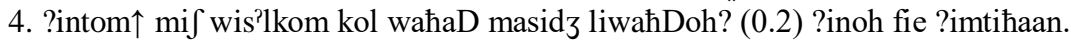

Did not you $\uparrow$ receive a private message $(0.2)$ ? That there is a mock exam?

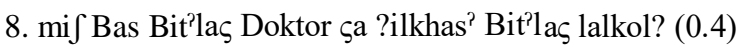

$$
\text { الطالب: مش بس بطلع دكتور ع الخاص بطلع للكل؟ (0.4) }
$$


It is not just a private message, but also a public one (0.4)

$$
\text { الدكتور: للكل؟ خلص؟ أنا بعرفش شو الي بصير عندكم بس يعني مبارح حنتوني }
$$

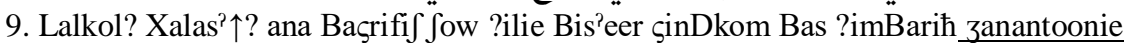

For all of you? Enough $\uparrow$, I do not know what happens with you? Anyhow, yesterday, you drive me crazy

بصراحه اشي غريب عجيب يعني تقول أنا قاعد بسولف مع ناس بالصف الرابع. (0.1) 10.? iBs'arah ?ifie yareeB çazeeB Yaçnie ?itgool ?ana gaçiD Basoolif maৎ naas Bils?af ?ilraBiç (0.1) It is really strange. I mean it is like dealing with year four school students. (0.1)

14. Yaşnie as?ilih ?imBarih JaraBatnie 4 magaat gahwih

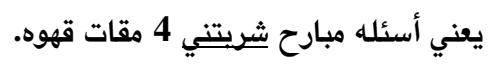
All yesterday questions caused me to drink four mugs of coffee.

$\cdot$

25. Ba?owl lie $\int$ yicTard?ow $\downarrow$ calaa ?ilwaqt fasaçiythaa

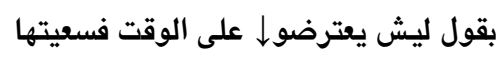
I asked myself about the reason beyond students' disagreement $\downarrow$ on the pre-mentioned time.

$$
\text { انتبهت اني أنا معطيكو وقت مين الشعبه التانيه. لما قال أنا }
$$

26. ?intaBahit ?inie ?ana mast'iykow meen ?iljoçBih ?iltanyih. lamaa gaal ?anaa

I discovered that I gave you the time of the second section mock exam,

عندي امتحان ب اييييييييي نفس وقت شعبتي فانتبهت.على كل على كل (0.3)

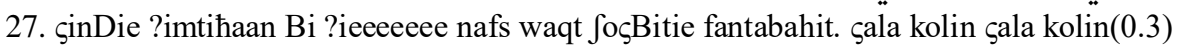
When one of the students said he has an exam at immm the same time. Anyway (0.3)

28. Rah yikoon ?ilwaqt Bas Xamis Daqa?iq $\downarrow$ ?il?imtihaan (.)

$$
\text { رح يكون الوقت بس خمس دقائقل الإمتحان (0.3) }
$$

The mock exam will be just five minutes $\downarrow$. (.)

From lines 3-9, the conversation is about how the students received the doctor's notification about the mock exam. In line 10, the doctor used informal item when he said Xalas? (enough) signaling the beginning of ST. Xalas ${ }^{2}$ is an imperative verb used to close the running sequence about the mock exam. It is an evidence of closing a sequence and beginning of a new context wherein ST occurs. ST is also realized using another informal item which is the phrasal verb zanantoonie (you drive me crazy). The doctor talked about how he was so annoyed by some of the students' questions a day before the class. He also described some students as school students in their year four. The students then explained why such questions were raised and clarified that the doctor made a mistake while assigning the exam time. In lines 25-26, the doctor admitted his mistake which confused the students and explained how he discovered that mistake. He then shifted back to the original topic in line 27 by using informal prepositional phrase sala kolin (anyway). This phrase means in Arabic that a speaker wants to close the running topic and immediately shifts to a new topic. In this example, the doctor used it to close the ST and shift back to the MT about the mock exam.

In addition, repeating sala kolin twice in the same turn may indicate self-initiated repair structure in which the doctor bought time to organize his ideas before shifting back to the main topic. A similar case of repetition of the same word or phrase in the same turn has been discussed by Al-Harahsheh (2015), who considered it a way to initiate self-repair for the purpose of organizing thoughts. Furthermore, both 
The Pivotal Role of Small Talk in Distance Teaching During

Covid 19 Curfew Period

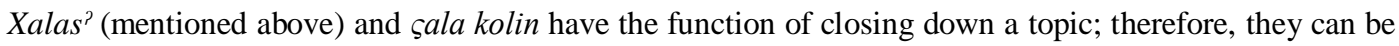
classified as 'topic shaded' (Schegloff and Sacks 1973).

In this extract, ST occurred in the form of TST (Hudak and Maynard 2011) because, firstly, the doctor opened a new line of topic in line 9 when he expressed his irritation from the students' questions. Secondly, students accepted ST turns and collaborated in the interaction. The occurrence of ST in this example is relevant to the MT: the mock exam and its time. The purpose of this ST is to clarify the mistake the doctor made.

The case in the next extract shows another example of ST that supports the main topic of the lecture.

\section{Extract 2}

5. haDowl ?il 'FOUR lung volumes'

These are the 'FOUR lung volumes'

طبعا؟ احنا مسجلين المحاضره على الفيسبوك يعني بتقدرو later ترجعو للمحاضره والي مالحق وراي يوخدها

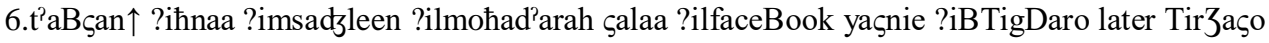
lalmohad'arah wa ?ilee malahag waray yowXiDhaa

Surely $\uparrow$, all the lectures are recoded and saved on the Facebook page of our class. This means you can re-listen to them later to take notes of the missing information

In this example, the professor $r$ summarized an idea to the students. At the end of his summary, he code switched to Arabic, the doctor's first language (L1), while he was shifting away from the lesson topic. Teachers would switch to their L1 when they shift from one topic to another (Gulzar 2010; Bensen and Cavusglu 2013). Code-switching also occurs to serve pedagogical and instructional purposes (Ma 2019). In this extract, it seems that switching occurred because the doctor wanted to give some instructions for the students. The doctor began the ST by telling the students that the lecture is recorded on Facebook, so it would be easy for students to listen again to them to take notes of the most important points. Therefore, the occurrence of ST here clarifies the importance of recording the class as it informs the students that they will not miss any part of the lecture. At the beginning of ST, the doctor used the cognate object $t^{2} a B$ san (surely) to confirm the availability of the lecture on Facebook. The use of this object can confirm either an already opened topic or upcoming information.

It appears that ST here is supportive to the main topic because it informs the students to go back to their lecture at any time to take notes about the tackled topic of the class. The type of ST in this extract may come under Brief ST (Hudak and Maynard 2011), as the doctor received no response from his students. The students did not reply to the doctor's turn, which declined the extension of ST.

In the following extract, ST occurs when the doctor blamed a student for not following his guidelines.

\section{Extract 3}

$$
\text { الدكتور: الان بدي أفهم من--- (.)شو؟ هو هذا التنظيم الذاتي؟ }
$$

1.?il?aan BiDie ?afham min (name) Jow $\uparrow$ howa haðaa ?ilTanð’eem ?ilðaaTie?

Now I want to know from (name)(.) what $\uparrow$ is the auto regulation? 


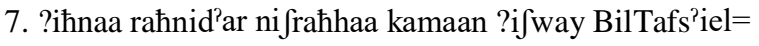

الطالب: احنا رح نضطر نشرحها كمان شوي بالتفصيل =

We have to explain it in details soon=

10. DokTor gaBil maa noDXol fiehaa nifraћhaa [CBB] $\downarrow$

الطالب: دكتور قبل ما ندخل فيها نشرحها]CBB] لـ.

Before discussing it (Auto regulation). [CBB] $\downarrow$

11. [la la la] maa Bidie $\uparrow \mathrm{CBB}$ la BiDie ?il?aan gaBil CBB

الدكتور: [لا لا لا] ما بدي

[no no no]I do not want $\uparrow$ to discuss CBB. I want to discuss auto regulation now before CBB.

الدكتور:عشان هيك أنا قلتلكوا اتقيدوا بالنسخه الجديده للكتاب. انت ؟يا --- راجع لنسخه قديمة (.)

12. Sa faan heek?anaa golTilkow ?iTqayaDow BilnosXah ?ili3DieDih lalkiTaaB.?inta $\uparrow$ yaa

(name) raßiৎ lanosXah qaDeemih

This is why I told you to stick to the latest edition of the text book. (name)! You $\uparrow$ used an old edition. (.)

موضوع CBB موضوع منفصل رح يجي later وهذا خطأك يا---!

17. Mawd'owৎ CBB Mawd'owৎ monfas'il rah yiḑy later wa haðaa Xat’a?ak yaa (name)!

CBB topic is a separate one. We will discuss it later. This is your fault, (name)!

قلتلك ابعثلي ال 'one week before' slides'. انت اليوم جاي تبعثلي اياهمر, بعثتلي اياهم يوم الإثنين دققتلك عليهم

وديتلك اياهم ،ترجعلي اياهمم ما رجعتلي اياهم(0.2)

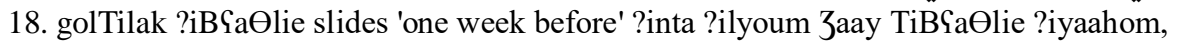

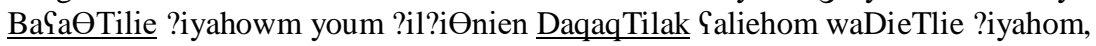

?iTradziSlie ?iyahom maa radzaSTilie ?iyaahom (0.2)

I told you to send me the slides one week before your presentation, but you sent them today. You

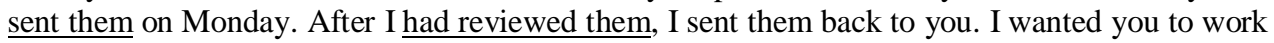
on the amendments and send them back to me, but you did not. (0.2)

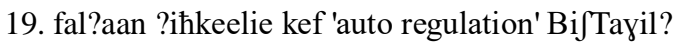

فالان احكيلي كيف 'auto regulation'بشتفل؟

Now tell me how the 'auto regulation' works?

In line 1 , the lecturer asked the presenter to explain 'auto regulation', but the presenter told the professor in line 10 that he wants to explain 'CBB' first. The doctor, in his turn, insisted on discussing the 'auto regulation' first. He then shifted from the topic of the lesson to ST using informal spoken language. The professor shifted to talk about the old version of the assigned textbook that the student used to prepare his presentation, which caused some conflict with what the students should learn in and prepare for the class. Also, the professor blamed the student for not sending back the slides a day before the lecture to have a final look at them. All this ST relates to and supports the MT about what the presenter has to prepare and discuss. The professor wanted to convey a message that the student did not prepare very well because of the two points that he mentioned in his ST about using the old version of the textbook and not returning the slides to the doctor. Therefore, on-topical ST (Hudak and Maynard 2011) is the type that describes ST in this extract. The on-topical ST in this example emerges when ST proceeds on the main running topic about discussing 'auto regulation' before CBB. This ST pro-offered a new topic about blaming the student for not sending the slides to the doctor one week before the class. The linguistic evidence used to identify this type of talk is the use of the linking word Gafaan heek (this is 
The Pivotal Role of Small Talk in Distance Teaching During

Covid 19 Curfew Period

why). In the current example, this word shows that the new pro-offered topic (ST) is a justification for the ongoing topic. This means that ST expands the ongoing topic.

In line 19, the professor began pulling back the talk to the main agenda using the conjoined faa? (then), which means that turns occur consecutively. Its role in the current example is to join the end of ST in line 18 and the main topic about 'auto regulation in line 19. The conjoined faa? is attached to ?il?aan (now) performing two functions: as a deictic expression which refers to time; and as a discourse marker which organizes the turns. This contrasts with Huang (2011), who reported that the combination of 'now then' is a lexical collocate which performs one function as a deictic expression. Only the free standing now, for him, functions as a discourse organizer.

In a few cases, ST occurs in a form of a joke, as in Extract 4 below:

\section{Extract 4}

الطالبه1: اتفوقت النساء على الرجال في حالات السكته الدماغيه بزيادة حوالي 60 الف امرأه أكثر من الرجال 1.?iTfaqaT ?ilnisaa? çalaa ?ilriZaal fie halaaT ?ilsakTih ?ilDimaayiyih BiziyaDih hawalie 60 ?alf ?imra?ah ?akӨar min?ilriZaal ?ieee( 0.2$)$

The percentage of females in stroke is higher than males. It is about 60 thousand more females than males

.

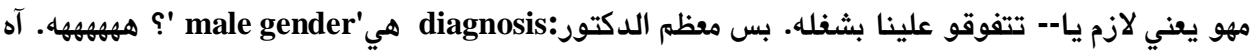

5. Mahowa yaçnie laazim yaa (name) TiTfawaqow çaleenaa Bifaylih Bas moşðam diagnoses hie 'male gender' hhhhhh ?aah?

(name)! You must outperform us in a disease, but most of the diseases attack males. hhhhh. right?

6. Falaazim TiTfawaqow çaleenaa ?iB $\int$ aylih zay stroke $=$

فلازم تتفوقو علينا بشفله زيstroke

So you must outperform us in such a thing as stroke=

7. $=$ ?iTfawaqnaa $\varsigma$ aaleehom [Bi heart] attack

$=$ We outperform them in heart attack

الطالب 2: = اتفوقنا عليهم بل attack [heart]

[BilzaBt? ${ }^{2}$ BilzaBt?

الدكتور: [بالزبط] بالزبط

Of course, of course

In the first line, the presenter (a student) mentioned that the percentage of females in brain stroke is higher than males. The lecturer, in line 5, shifted to informal talk using a joke with the presenter by saying that females must outperform the males in a disease, as most of the diseases attack males. The occurrence of joke here is tied to the content of the lesson, which is called by Vance (1987) as 'integrated humor'. The professor followed the joke with a short laughter which may indicate amusement and accommodation. This extract identifies another type of ST which is on-topical, as the doctor's ST is an elaboration on the running topic. He began the ST with simple present verb yagnie (mean) which has the semantic function of elaboration. This function matches with what was found in Rieschild's (2011) study, but it contrasts with Al-Harahsheh's (2015) study. Al-Harahsheh found that Jordanians used yagnie as a repair and clarification of what has been said before. 
This ST is closed with the informal item BilzaBt' (of course) which has similar meaning to t'aBçan mentioned in extract 2 , but it has different function. It is used to confirm what has been already said, not what will be said.

In line 7, another student kept the ST running by giving a counter example of a disease, in which the percentage of males is higher than that of the females. ST in this extract is part of the conversation and supports the MT because the doctor supported the presenter's information by giving a joke. The occurrence of ST in the form of joke was noticed by Hudak and Maynard (2011) and Abu-Elrob (2019b), who considered the joke a form of ST. Abu-Elrob reported that jokes are relevant to the main topic of medical talk.

In the next extract, ST occurs in a different form to support the main topic.

\section{Extract 5}

الطالب 2: طيب دكتوره انا غيرتها (.) أنا غيرتها في الMain ليش؟ حتى أرجع أطبقها في الglobal variable

'function'

11. t’ayiB DokTorah ?anaa yayarThaa (.) ?anaa yayarThaa fie ?il main lie $\uparrow \uparrow$ haTTaa ?arZaৎ ?t'aBiqhaa fie ?il 'global variable function'?

Ok Doctor. I changed it in the main Why $\uparrow$ do I change it in the 'global variable Function'?$$
\text { لأنه global زي ما تؤلي كيف BOX خارجي وكل هالناس عم تيجي بتحط فيه أو بتفير فيه...فأي واحد بتفير }
$$$$
\text { الناس الثانيين }
$$

14. li?anoh gloBal Zay maa ?iT?owlie keef BOX XariZee wa kol ?ilnaas Sam TieZie BiThot? fie ?aw BiTyayer fieh. Fa?ay waahaD Biyayier ?ilnaas ?ilTanyen because it is global. It is as an external BOX and all people fill it or change it... so others

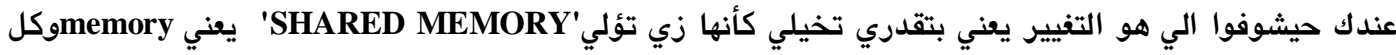

$$
\begin{aligned}
& \text { الناس عم تستخدمها }
\end{aligned}
$$

15. SinDak hayfowfow ?ilie howa ?ilTayeer ya@nie ?iBtigDarie ?iTXayalie ka?anhaa zay ?it?owlie 'SHARED MEMORY' ya@nie memory wa kol ?ilnaas Sam TisTaXDimhaa will see that change. Imagine it as a 'SHARED MEMORY' that all people use.

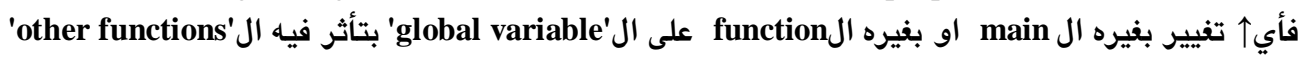

16. Fa?ay $\uparrow$ Tayeer Biyayroh ?li main ?aw Biyayroh ?il function Salaa ?il 'golobal variable'

BiT?aӨar fieh ?il 'other functions'

So any $\uparrow$ change on the 'global variable' will be reflected on the 'other functions'

In line 11, the student asked a question in a Math class. In line 14, the professor introduced ontopical ST in the form of simile using Zay maa ?iT?owlie (like what you say). She also mixed the two languages, English and Arabic, to answer the question. This shift to talk about a box or a memory might seem irrelevant to the main topic, but the doctor was keen to show the connection between the given simile and the student's question making the ST supportive to the main topic. The ST here describes a process of change, people can make, which is related to the MT the doctor tries to explain about the change in the global variable. This relationship is supported by the use of the conjoined faa? (then), similar to what has been reported in extract 3 above. It can be considered a connector, in addition to be a discourse organizer, because it links between the end of ST and the reopening of the MT of the class. 
The Pivotal Role of Small Talk in Distance Teaching During

Covid 19 Curfew Period

\subsection{ST relevant to the learning process}

The examples below show how ST is part of and related to the learning process. In Extract 6, ST occurs when the professor wanted to check the attendance of one of the students, as follows:

\section{Extract 6}

الدكتور: هل هناك changes على هؤثر على قراءة الICB (0.7)

1. Hal honaak changes §alaa haaðaa CFF yo? Oir çalaa qiraa?iT ?il ICB (0.7)

Is there any change in $\mathrm{CFF}$ that influence ICB? (0.7)

3. $=($ name $)$ hakaT yes?=

$=($ name $)$ said Yes?=

الدكتور: --- حكت Yes

الطالبه 1: =----" حكت [Yes]

4. $=($ Name $)$ hakaT $[$ yes]

$=($ name $)$ said [yes]

5.[name] Bas Bit’las sinDiy ka?inoh ?isim(name) $\downarrow !(0.1)$

But it is (name) name on the screen $\downarrow$ ! (0.1)

6. Laa ?ana hakeeT yes

No I said Yes

7. t'ayiB (name) ween $\uparrow$ yaa Zamaaçah?

الدكتور: طيب ---وين ؟ يا جماعه؟

So, where is(name) $\uparrow$, guys?

8. haat'ah comment ?inoh fee $\int$ tayt $^{2}$ iyih sinDhaa

She sent a comment that there is no internet connection

الدكتور: [---] بس بطلع عندي كأنه اسـم --- لـ (0.1) !

Yes الطالبه1: لا انا حكيت .

'to call her by phone' لمدة دقيقتين خلي وحده من البنات break الدكتور: طيب ممكن ناخذ بس 10. t'ayiB momkin naXoD Bas break lamoDiT Daqaqteen Xalie wahDih min ?ilBanaaT to call her by phone

Ok. Let's take a break for two minutes until one of the girls contacts her .

12. Yalaa Doktor

الطالبه 2: 20لا دكتور

Ok doctor

15. ?ieeee DokTor (name) ?iBTiћkee ?inhaa Bilqisim

الطالبه 3: اييي دكتور --- بتحكي انها بالقسم Imm, Doctor! She says that she is in the Work.

16. [t'ayiB]

[ok]

17. [?alow] ?ah. wa qismhaa closed maa fie JaBaaBiek Yasnie

الطالبه 3: [الو]اه. و قسمها ما في شبابيك يعني [Hello] ok. And there are no windows in her department. 
الدكتور: طيب ما هي بتعرف المفروض اليوم تكون على المحاضره ليش بالقسه؟؟ (0.4) 18. t’ayiB ma hie ?iBTiçraf ?ilmafrod? ?ilyowm ?iTkoon çalaa ?ilmoћad'arah lie S Bilqisim? (0.4) Ok but she knows that today is our class time. Why is she there? $(0.4)$

$$
\text { الدكتور: ويوم الأربعاء معروف انه محاضرتنا ع } 2 \text { ولازم تكون معنا على المحاضره فهي غياب اليوم بلفوها }
$$

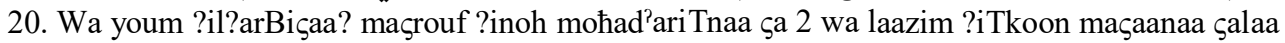
?ilmohad'arah fahiyi yiyaaB ?ilyowm Balayohaa

Our lecture is on Wednesday at 2:00 and she must attend. Thus, tell her that she is absent for today.

$$
\text { بس بعد المحاضره وهذا غياب غير مبرر. لأنه احنا نتخيل حالنا بالجامعه بتكون ع الدوام يوم الأربعاء؟؟ }
$$

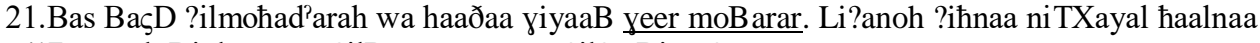
Bilßaam̧ah Binkown ̧a ?ilDawam yowm ?il?arBiçaa?

After the class, tell her that her absent is Unjustified because in the normal situations we must be in the campus on Wednesday to attend the lecture.

\section{الدكتور: والله يعني المهم'this is not an acceptable excuse' . طيب انكمل يا --- اتفضل.}

23. Wallah yaçnie ?ilmohim this is not an acceptable excuse. t'ayiB ?inkamil yaa (name)

?itfad'al.

This is unjustified excuse. Ok go ahead (name).

When the doctor asked a yes-no question, one of the students replied with yes. The doctor then wanted to check who that student is and discovered that the student's name is replaced by another name on his screen. Therefore, he asked where the student, whose name appeared on the screen, is and discovered that the student was not active for a reason, as mentioned in the conversation. Thus, the doctor considered her absence unjustifiable.

Although the doctor was asking a question relevant to the topic of that class, the answer of one of the students led the doctor to shift to ST; to look for another student and to have a break to contact that student. This ST was formed when the doctor shifted from the classroom MT to informal spoken one, which does not relate to the topic itself, but it is part of the lecture, possibly except for the time used for calling the student, to check the attendance of the students. This way of checking the attendance, imposed by the nature of the distance learning, can be useful to see if the students are following the doctor and to make sure that they are engaged in the learning environment. Moreover, the shift from the main topic of the lesson to check the students' attendance comes under TST. It begins when the doctor discovered the absence of one of the students and proceeds when the students engaged in the interaction to figure out where the student was. The doctor used the noun $\mathrm{t}^{\mathrm{T}} \mathrm{ayiB}(\mathrm{Ok})$ which performs two different functions. The first is in line 7 to shift from the main topic to ST having the meaning of what happened then. The second is in line 23 to close ST. The two functions of 'Ok' show continuation and closure usage (Beach 1993). The continuative function of tayiB (Ok) indicates a transition to another utterance in the same turn which is the question 'where is (name) $\uparrow$, guys?'. This agrees with Ebshiana (2020) who found that a combination between 'Ok' and other responses is needed to invite students to contribute for further talk.

Also, the process of checking if the students are following their doctor occurs in another example in a humor type of ST, as in the following extract. 


\section{Extract 7}

الدكتور: هلا انا سؤالي بدي اسأل على سويسري فرانك (0.2) ارتفع ولا انخفض بالسعر الاجل؟ شوصار؟؟ 1.Ha? ?anaa so?aalie BiDee ?as?al çalaa sweesrie frank (0.2) ?rtafag wila ?inXfad? Bilsiçir ?il?aaßil? Jow s'aar $\uparrow$ ?

Now my question is about the Swiss Frank. (0.2) Is it raised or came down in the forward price? What happened?

·

8. (name)? (0.4)

الدكتور: ---9)(0.4)

الدكتور: --1III

9. ((the doctor is calling the student in a stretching sound $)$ )

10.((The students are laughing))

11. Maçak DokTor=

I am here $=$

12.=?ilhamDolilah ̧ala ?ilsalaamih $\downarrow=$

$=$ Welcome back $\downarrow=$

13.=Laa walah maçak maçakBas konT gaaçiD Bas'alie $\downarrow$

الطالب: =لا والله معك معك بس كنت قاعد بصليل.

\section{.}

الدكتور: كيف صارت يا زلمه ل\ربلي اياها. بغض النظر يعني بتصلي ولا بتاكل ولا بتفطر (.)على كل تقبل الله 16.Keef s'aaraT yaa zalamih $\downarrow$ rakiBlie ?iyaahaa Biyad? ?ilnað’ar yaçnie Bits'alie Wila ?BTakol wila ?iBTift'ir (.)çala koleen TaqaBal Allah

How is that, man $\downarrow$ ! Explain. It does not matter if you are praying, eating or having

Breakfast (.) Anyway, may Allah accept your pray

الطالب: منا ومنك، اسمعت اخر شي انه السويسري فرانك بكون عالي ولا واطي صح ولا لا؟

17. Mina wa minak ?smiçiT ?aaXir Jie ?ino ?lswesrie frank Bikown çaalie welaa wat'ie s'ah wela la??

Thank you. The last thing I heard was whether the Swiss Frank is high or low, right?

The doctor here asked his students a question and was waiting for their answers. In line 8, the doctor called a student to answer his question, but he did not reply. In line 9, the doctor called the same student again in a funny way that turned the conversation to informal talk and encouraged the students to laugh. The humor in this example is similar to the occurrence of the joke in extract 4 in that it is tied with the content of the class. The doctor developed the ST humorously using the nominal sentence ?ilhamDolilah sala ?ilsalaamih (welcome back). The student confirmed that he was listening to the doctor and justified his disappearance humorously. In line 16, the doctor reacted humorously as he does not believe that the student was listening to his question. He then closed the ST using the prepositional phrase cala kolin, similar to what is observed in extract 1 above. sala kolin is followed by an invocation TaqaBal Allah (may Allah accept your pray) which functions as another closure. Invocations, according to Abu-Elrob (2019a), are used to close a sequence in the medical talk. In line 17, the student accepted the closing and shifted back to the main topic. 
In the upcoming extract, the case is a little bit different because the presenter missed the connection with the whole class, the matter that caused ST to occur.

\section{Extract 8}

2.?ils'owT masmos sinDkom?

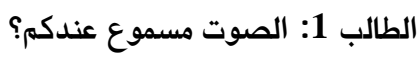

Can you hear the voice?

$$
\text { الدكتور: مين الي بحكي؟ آه ---؟ --- معي؟ (0.3) ---! --- مش سامعتينا؟؟ (0.1) حدا يحكي معها }
$$

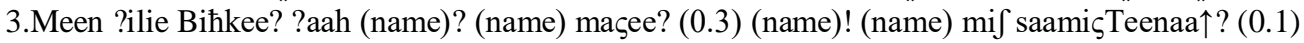

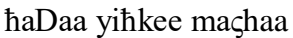

Who is talking? Oh (name)?(name) with me?(0.3) (name)! Can you hear us $\uparrow$ (name)? (0.1) please Can somebody call her

5.Rah niћkee machaa DokTor=

$$
\text { الطالب 2: رح نحكي معها دكتور= }
$$

We will call her, Doctor!=

((A phone call between student 1 and another student))

-

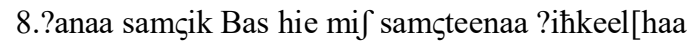

الدكتور: انا سامعك بس هي مش سامعيتنا احكيلل[ها I can hear her but she cannot hear us

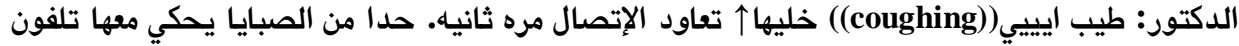
26.t’ayiB ?iee ((coughing)) Xaleehaa $\uparrow$ ?iTçaawiD ?il?itis’aal marah Oaanyih. haDaa min ?ils’aBaayaa yiћkee machaa Telefown

Ok.imm ((coughing)) Ask her $\uparrow$ to reconnect. Can one of the girls tell her to reconnect us?

الطالب 2: دكتور هيني فصلته وقاعد أرن عليه مره ثاني (0.5) 29.DokTor haenee fas’alThaa wa gaaçiD ?arin çaleehaa marah Өaanyeh (0.5)

I am trying to re-contact with her ended (0.5)

الدكتور: احنا الي ضايل علينا نقطتين فقط'diagnostic processing' و

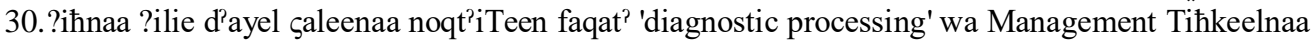
?iyaahom wa BaçDeen noDXol fie we still need to discuss the 'diagnostic processing' and Management that she needs to explain.

الطالب 2: مافي عندها نت لانه بجيبلي هيunavailable 34. Mafie sinDhaa neT li?anoh BidzeeBlie hie unavailable $=$ She is not available $=$

35.=? aah Jeklow s'aar fie Xalal sinDhaa fie ?ilneT $\downarrow$. ?ah?

الدكتور:= آه شكلو صار في خلل عندها في النتلـ. آه؟ $=$ It seems she has an internet connect problem $\downarrow$, right?

((Student 2 is calling student 1$)$ ) 
The Pivotal Role of Small Talk in Distance Teaching During

Covid 19 Curfew Period

الطالب 2 للدكتور: هيا دكتور معانا

37. Hayhaa DokTor maçanaa

She is with us

(0.9) ok: الدكتور

38.Ok (0.9)

39. Samseen ?ils'owT. s'aћ?

You can her me, right?

الدكتور: الم---ok

40.Ok (name)

42. mi mofkilih (name) welcome back yalla ok

الدكتور: مش مشكله---'welcome back' يلا no problem (name). Welcome back. Ok, let us

In this extract, one of the students is a presenter who lost connection with the whole class. In line 2, the presenter raised a question, shifting the conversation away from the topic being discussed to check if the class is hearing her. The doctor noticed that there was a connection problem which was solved after a while, as seen in lines 3-39. The presenter then had apologized for what happened before the doctor pulled the conversation back to the topic of the presentation using both yalla and $o k$. This word is the shortened form of the vocative case ya Allah (O God) which is commonly used to speed up the upcoming action. It was used in this extract to let the student resume the presentation, as it can be inferred from the context that the doctor wanted to say ya Allah nabda?/nacoud (let us begin/go back). Furthermore, the combination of yalla and 'Ok' functions as launching another action in a new turn. In a previous study by Ebshiana (2020), it was noticed that a combination between 'Ok' and other responses contributes to topic shifting. Yalla and 'Ok' are a response to the student's apology and are employed to close ST sequence and return to the main topic of the class.

The ST appears in this extract is part of the distance learning environment because the lecture was live and connection problems are likely to happen. These problems must be solved to complete the class successfully to achieve the desired learning outcomes. The type of ST occurs here is TST. It includes a shift from the main topic of the lesson and a collaboration to develop a new topic on a current event, which is the loss of connection.

The last example of the occurrence of ST as part of the learning process appears in Extract 9 below:

\section{Extract 9}

الطالب: دكتور هسع ال اييييي انه القيم الطبيعيه ايي لل 'main intra pressure ' انه بكون اقل من 160 1. DokTor hassa ? ?il ?ieeee ?noh ?ilqiam ilt’aBeçieh ?ieee lal main intra pressure ?inoh Bikown ?aqal $\min 160$

Doctor! the normal values of the main intra pressure should be less than 160

الدكتور: ----- 
7. (name) try to speak English (0.3)

'must be with accatable range '() 'auto regulation to be function' الطالب: هسه بحكيلنا

8. Hassah Behkeelnaa auto regulation to be function () must be with accatable range So the auto regulation must be accatable to function ()

الدكتور: Acceptable range. Acceptable. Acceptable

الطالب:

الدكتور: آه انا حكيتلكو اديرو بالكو على قراءة ال slides(.)وهذا تحاسب عليه. يا جماعه لفتكو الإنجليزيه بدها

11. ?aah ?ana ћakeetilko ?iDeero Balko calaa qira?iT ?il slides (.) wa haðaa ToћaasaB çaleeh. Yaa dzamaaçah loyaTkow ?il?ingleeziyih BiDhaa TiThasan.

Yes. I told you before to prepare the slides very well(.) because there will be mark on your reading for the slides. Guys! Your English Language should be better.

\section{قبل شوي حكينا.'within acceptable range' كلمة2 provid. PROVIDE مش؟ آه؟}

12. QaBil ?fway hakeenaa 'Within acceptable range'. kalimiT provid (.) mi provid. BROVIDE ?aah?

Before a while I said 'Within acceptable range'. The word provid is incorrect. It is BROVIDE. Ok? In this extract, the student switched between English and Arabic during presentation, but the doctor in line 7 shifted to ST to encourage the student to use English only. When the student switched to English, he mispronounced a word which was repaired by the doctor. In line 11, there is another occurrence of ST wherein the doctor code switched to Arabic to stress the importance of improving the students' English language and of reading the slides before the class. Despite the doctor's insistence on speaking English in the classroom, he switched to Arabic (L1) for instructional purposes. The doctor used the simple past verb ?aah (yes) to confirm what he wants to say about what has already been discussed. However, the doctor did not receive any response from any students, causing brief ST to occur. Although the ST about the importance of using good English is not related to the nursing topic being discussed, using English is part of the students' study. Therefore, ST here relates to the aim of the course in general and supports it.

The extracts above reveal some lexical items that contribute to identify the shift to ST and the end of it. These are summarized in the rubric below with the function they perform:

Table 1: Linguistic rubric

\begin{tabular}{ll}
\hline \multicolumn{1}{c}{ Lexical item } & \multicolumn{1}{c}{ Function } \\
\hline $\begin{array}{l}\text { Xalas? (enough) } \\
\text { cala kolin (anyway) }\end{array}$ & - closing a sequence and opening another \\
\hline $\begin{array}{l}\text { t'aBcan (surely) } \\
\text { ?aah (yes) }\end{array}$ & - confirming upcoming talk \\
\hline cafaan heek (this is why) & - shifting to a new topic without closing the running one \\
& - shifting to a new topic without closing the running one \\
\hline Conjoined faa? (then) & - introducing actions consecutively \\
& - shifting to a new topic without closing the running one (linking talk turns) \\
\hline Yacnie (mean) & - elaboration on MT with a shift to ST (no closing marker) \\
BilzaBt (of course) & - confirming previous talk \\
\hline Zay (like) & - closing MT or ST \\
\hline t'ayiB (what happened & - simile \\
then) & - shift to ST without closing marker (linking talk turns) \\
\hline t'ayiB (ok) & - closing a sequence \\
yalla (O God) \& ok & - closing a sequence and opening another \\
\hline
\end{tabular}


The Pivotal Role of Small Talk in Distance Teaching During

Covid 19 Curfew Period

The main function that all the lexical items in this table share is that they indicate a shift from the running topic. The difference between them is in signaling the close of a sequence. The items Xalas? çala kolin, BilzaBt? and t'ayiB: (ok) indicate that a sequence is closed before shifting to another topic. The remaining items show that the shift to another topic is not interrupted by a closing marker.

\section{Conclusion}

The departure from the classroom talk to ST is a notable feature in the distance learning environment that has taken place during Covid 19 pandemic. Generally, the occurrence of ST is noticeable at the boundaries of conversations (Laver 1975; Holmes 2000), whereas the present study shows that it tends to be positioned in the middle of the conversations. In this paper, the relevancy of ST is in two folds: relevant to the main topic of the class, in five examples, and relevant to the learning process in general, in 12 examples. The relevancy of ST to classroom talk indicates that it is not purposeless one. It can be ontopical ST which is one of ST types that showed how ST is built on the ongoing topic of classroom. This matches with Hudak and Maynard (2011) and Abu-Elrob (2019b) who found that non-serious talk is ontopical in the medical consultations. Some other types of ST also appeared in the present study and showed a connection with classroom talk, these are brief ST, TST and humor. Brief ST and TST showed how ST is developed or discouraged. In TST, participants accepted ST invitation and collaborated to develop it whereas in brief ST, participants rejected ST as there was no response produced.

The reciprocation of ST between participants occurs when participants are engaged in ST, as shown in the present data. This means the acceptance of the invitation to take part in ST. This engagement in ST between participants might establish a relationship between them or indicate that there is an already exited relationship between them. This kind of interaction may create rapport which can facilitate the interaction in classroom. For example, students may cooperate better in the classroom with the teacher either at the academic level or at the behavioral. They are likely to cooperate with their colleagues and participate in the classroom without feeling embarrassed.

As for the humorous type of ST, it was also supportive to the main topic or the learning process. Its occurrence might give an indication about establishing a positive relationship between the teacher and his students. The crucial role of humor in classroom teaching was noticed in offering a positive relationship between participants in classrooms; in reducing sensitive feelings, such as embarrassing, tension and stress; in facilitating the learning process and in maintaining students' attention and positive emotions (Cornett 1986; Herbert 1991; Aboudan 2009; Jeder 2014; Sambrani and Jakubovski 2014). On the other hand, this type of ST proffers a possible new topic (Hudak and Maynard 2011), which may go further than needed from the main topic. It happened that humor talk led to a new expanded topic in some examples in this paper, but connection with the main agenda has been maintained.

In the discussed extracts, speakers shift from the main topic of the class to ST and then gradually pull the conversation back to the class topic. These divergent degrees of presenting ST may help present the speaker's message clearly by finding an opportunity in using ST to explain an idea in more details and 


\section{Abu-Elrob, Tawalbeh}

to give examples or jokes. Including jokes or humor in classroom talk may play a role in attracting students' attention to the lesson in a funny and purposive way.

The analysis of linguistic features reveals some items that would signal the beginning and closing of ST. Items such as $t^{2} a y i B$ : what happened then, conjoined $f a a$ and Yasni, have a linking function; therefore, they may be considered an evidence of the relationship between ST and classroom talk. The analysis of the data at the bottom level also reveals the occurrence of code switching and the use of informal spoken language. These phenomena seem to play a role in shifting to ST. It can be said that the participants' switch to informal spoken Arabic is a context wherein ST is reinforced.

The findings of the study provide insights into the importance of ST in the learning environment. Therefore, training sessions could be held for teachers/ lecturers/ professors to suggest strategies that would skillfully develop and manage engaging ST in the classroom. Such strategies may achieve aims such as: 1. engaging students effectively in the classroom and maintaining their positive feeling; 2. facilitating the learning process; and 3. building a good relationship between teacher and students. Moreover, the training sessions may also include how to deploy humor in either normal or distance teaching classrooms to be useful for the aims of the class and to build a good relationship with students. Finally, teachers could be trained to train students how to use humor meaningfully to understand the lesson and memorize it (see Jeder 2015; McCabe, Sprute and Underdown 2017). 
The Pivotal Role of Small Talk in Distance Teaching During Covid 19 Curfew Period

\section{الدور المهم للحديث الجانبي في التعليم عن بعد أثناء جائحة كورونا}

$$
\text { قسم اللغة الإنجليزية، جامعة إربد الأهلية، الأردن }
$$

الملخص

يتكون الحديث البشري من أجزاء أساسية تساهم بشكل فعال لتبادل ومشاركة أطراف الحديث. هناك أجزاء أخرى في الحديث يمكن أن تساهم فقط في ملء الفراغ الناتج عن الصمت، وهذا ما يسمى بالحدث القصير. قد يكون السبب وراء هذه التسمية هو ظهوره على أطراف الحديث الأساسي وعدم تاثيره بشكل فعال على موضوع النقاش الأساسي. فإن هذه الدراسة لا تعني تجاهل هذا النوع من الحديث لأنه قد يكون هناك تأثير إيجابي له على موضوع الحديث الأساسي. ولهذا السبب هذه الدراسة تتناول الحديث الجانبي وتحلل ظهوره في الحديث الصفي أثناء عملية التعلم عن بعد لاكتشاف ما إذا كان له دور إيجابي على المحادثة الصفية أو فقط لملء الفراغ الذي قد يظهر أثناء النقاش الصفي. وقد أجرت الدراسة أيضاً تحليلاً لأنواع الحديث الجانبي وللخصائص اللفوية الدالة على حدوث الحديث الجانبي. لقد استخدم الباحثون نهج تحليل الحديث الذي يعتمد على التحليل العميق للتفاعل الكلامي المتضمن ترتيب الكلام وتتابعه وأدوار المشاركين في الحديث. لقد أظهرت النتائج أن هناك دوراً ايجابياً للحديث الجانبي القصير على عملية التعليم بشكل عام، وعلى موضوع النقاش الأساسي بشكل خاص. تقدم نتائج هذه الدراسة أفكاراً لأهمية تفعيل الحديث القصير أو الجانبي في المحادثة الصفية وكيفية إيجاد استراتيجية لتفعيله لغايات تطوير البيئة التعلمية. الكلمات المفتاحية: التعليم عن بعد، المحادثة الصفية، المحادثة الصغيرة، تحليل الحديث. 


\section{References}

Aboudan, Rima. 2009. Laugh and Learn: Humor and Learning a Second Language. International Journal of Arts and Sciences 3 (3): 90 - 99.

Abu-Elrob, Rula. 2019. Culturally Specific Patterns to Close a Medical Consultation in Jordan: A Conversation Analysis Case Study. International Journal of Linguistics 11(5): 265- 285.

Abu-Elrob, R. 2019. Doctor-Patient interaction at a jordanian university hospital. PhD diss., University of Huddersfield.

Al-Harahsheh, Ahmad. 2015. A Conversation Analysis of Self-Initiated Repair Structures in Jordanian Spoken Arabic. Discourse studies 17 (4): 397-414.

Aronsson, Karin and Ann-Christin Cederborg. 1997. A love Story Retold: Moral Order and Intergenerational Negotiations. Semiotica 114 (1-2): 83-110.

Beach, Wayne A. 1993. Transitional Regularities for 'Casual' “Okay” Usages. Journal of Pragmatics 19 (4): $325-352$.

Bensen, Hanife and Çise Çavuşoğlu. 2013. Reasons for the Teachers' Uses of Code-Switching in Adult EFL Classrooms. Hasan Ali Yücel Eğitim Fakültesi Dergisi 10: 69-82.

Boynton, Mark and Christine Boynton. 2005. The Educator's Guide to Preventing and Solving Discipline Problems. Alexandria, Virg: Association for Supervision and Curriculum Development.

Case, Alex. 2019. How to Teach Small Talk. Using English.com, retrieved from https://www.usingenglish.com/articles/how-to-teach-small-talk.html

Cornett, Claudia E. 1986. Learning through Laughter: Humor in Classroom. Bloomington: Phi Delta Kappa Educational Foundation.

Coupland, Justine. 2000. Small Talk. Harlow: Longman.

Coupland, Justine, Nikolas Coupland and Jeffrey Robinson. 1992. 'How Are You?': Negotiating Phatic Communion. Language in Society 21 (02): 207-230.

Ebshiana, Asma. 2020. Response Tokens and their Sequential Action in the Teacher Third Turn (Note 1) A Conversation Analysis Case Study in the EFL Classroom. International Journal of Linguistics 12 (2): 26-43.

Gulzar, Malik A. 2010. Code-Switching: Awareness about its Utility in Bilingual Classrooms. Bulletin of Education \& Research 32: 23-44.

Herbert, Patrick J. 1991. Humor in the Classroom: Theories, Functions, and Guidelines. Chicago, IL: Central Status Communication Association.

Holmes, Janet. 2000. "Doing Collegiality and Keeping Control at Work: Small Talk in Government Departments". In Small talk, ed. Justine Coupland, 32-61. London: Routledge.

Holmes, Janet and Maria Stubbe. 2003. Small Talk and Social Chat at Work. Power and Politeness in the Workplace: A Sociolinguistics Analysis of Talk at Work. London: Longman.

Huang, Lan-fen. 2011. Discourse markers in spoken English: a corpus study of native speakers and chinese non-native speakers. PhD diss., University of Birmingham. 
The Pivotal Role of Small Talk in Distance Teaching During

Covid 19 Curfew Period

Hudak, Pamela and Douglas Maynard. 2011. An Interactional Approach to Conceptualizing Small Talk in Medical Interactions. Sociology of Health \& Illness 33 (4): 634-653.

Hutchby, Ian and Robin Wooffitt. 1998. Conversation Analysis: Principles, Practices and Applications. Cambridge: Polity Press.

Jaworski, Adam. 2000. "Silence and Small Talk”. In Small talk, ed. Justine Coupland, 110-13. Harlow: Longman.

Jeder, Daniela. 2015. Implications of Using Humor in the Classroom. Social and Behavioral Sciences 180: 828-833.

Langer-Osuna, Jennifer M. 2018. Productive Disruptions: Rethinking the Role of Off-Task Interactions in Collaborative Mathematics Learning. Education Sciences 8 (87): 1-11.

Laver, John. 1975. “Communicative Functions of Phatic Communion”. In Organization of behaviour in face-to-face interaction, eds. Adam Kendon, Richard M Harris, and Mary Ritchie, 215-238. The Hague: Mouton \& Co.

Leff, Stephen S., Tracy Evian Waasdorp and Brooke S Paskewich. 2016. The Broader Impact of FriendTo-Friend (F2F): Effects on Teacher-Student Relationships, Prosocial Behaviors, and Relationally and Physically Aggressive Behaviors. Behavior Modification 40 (4): 589-610.

Luk, Jasmine. 2004. The Dynamics of Classroom Small Talk. Issues in Applied Linguistics 14 (2): 115 132.

Luz, Fredson Soares dos Reis. 2015. The Relationship between Teachers and Students in the Classroom: Communicative Language Teaching Approach and Cooperative Learning Strategy to Improve Learning. BSU Master's Theses and Projects, Retrieved from http://vc.bridgew.edu/theses/22.

Ma, Lai Ping F. 2019. Examining the Functions of L1 Use through Teacher and Student Interactions in an Adult Migrant English Classroom. International Journal of Bilingual Education and Bilingualism 22: $386-401$.

Macdonald, Lindsay M. 2016. Expertise in Everyday Nurse-Patient Conversations: The Importance of Small Talk. Global Qualitative Nursing Research (3): 1-9.

Markee, Numa. 2005. "The Organization of Off-Task Talk in Second Language Classrooms". In Applying conversation analysis, eds. Keith Richard and Paul Seedhouse, 197-287. London: Palgrave Macmillan.

Maulana, Ridwan, Marie-Christine Opdenakker, Kim Stroet and Roel Bosker. 2013. Changes in Teachers' Involvement Versus Rejection and Links with Academic Motivation during the First Year of Secondary Education: A Multilevel Growth Curve Analysis. Journal of Youth and Adolescence 42 (9): 1348-1371.

Maynard, Douglas and Pamela L. Hudak. 2008. Small Talk, High Stakes: Interactional Disattentiveness in the Context of Prosocial Doctor-Patient Interaction. Language in Society 37 (5): 661-688. 
McCabe, Crystal, Katie Sprute and Kimber Underdown. 2017. Laughter to Learning: How Humor Can Build Relationships and Increase Learning in the Online Class. Journal of Instructional Research 4: 4-7.

Rieschild, Verna. 2011. Arabic Yacni: Issues of Semantic, Pragmatic, and Indexical Translation Equivalence. Intercultural Pragmatics 8 (3): 315-346.

Sambrani, Tanvi, Sneha Mani and Ewgeni Jakubovski. 2014. The Effect of Humour on Learning in an Educational Setting. International Journal of Education and Psychological Research 3 (3): 52-55.

Schegloff, Emanel A. and Harvey Sacks. 1973. Opening up Closings. Semiotica 8: 289-327.

Seedhouse, Paul. 2013. "Conversation Analysis". In The Oxford handbook of sociolinguistics, eds. Robert Bayley, Richard. Cameron and Ceil Lucas, 91-110. NewYork: Oxford University Press.

Sharma, Bal. (2014). Interactional Concerns in Implementing Group Tasks: Addressing Silence, Dominance, and Off-Task Talk in an Academic Writing Class. Innovation in Language Learning and Teaching 9 (3): 1-18.

Taylor, Stephanie. 2013. What is Discourse Analysis? UK: Bloomsbury.

Turner, George W. 1973. Stylistics. UK: Penguin Books.

Valencia, Diego. 2009. 'No Offense Guys': Some Ambiguous Functions of Small Talk and Politeness in Workplace Discourse. LCOM Papers 1: 17-32.

Vance, Charles M. 1987. A Comparative Study on the Use of Humor in the Design of Instruction. Instructional Science 16: 79-100.

Varga, Meagan. 2017. The Effect of Teacher-Student Relationships on the Academic Engagement of Students. Master thesis, Goucher College. 